\title{
ДИНАМИКА ВЫХОДА УГЛЕВОДОВ ПРИ ВЫСОКОТЕМПЕРАТУРНОМ ГИДРОЛИЗЕ ПШЕНИЧНОЙ СОЛОМЫ СЕРНИСТОЙ КИСЛОТОЙ
}

\author{
() М.В. Харина ${ }^{1 *}$, В.М. Емельянов ${ }^{1}$, А.Р. Аблаев ${ }^{1}$, Н.Е. Мокиина ${ }^{2}$, Н.Н. Ибрагимова ${ }^{2}$, Т.А. Горикова ${ }^{2}$ \\ ${ }^{1}$ Казанский национальный исследовательский технологический \\ университет", ул. К. Маркса, 68, Казань, 420015 (Россия), \\ e-mail: emelianov@front.ru \\ ${ }^{2}$ Казанский институт биохимии и биофизики Казанского научного центра \\ Российской академии наук, ул. Лобачевского, 2/31, Казань, 420111 (Россия), \\ e-mail:gorshkova@mail.knc.ru
}

\begin{abstract}
Исследовано влияние температуры и длительности обработки пшеничной соломы сернистой кислотой $(0,59$ и $1,18 \%$ масс.) на состав и содержание углеводов в гидролизатах. Независимо от температуры воздействия в исследуемых гидролизатах преобладала ксилоза (48,4-55,1 моль \% от суммы моносахаридов). Охарактеризована динамика выхода моно-, олиго- и полисахаридов при гидролизе пшеничной соломы сернистой кислотой $0,59 \%$ масс. при $190{ }^{\circ} \mathrm{C}$. Благодаря высокому содержанию пентозанов и, в частности, ксилозы, полученные гидролизаты перспективно использовать для производства ксилозы, ксилита фурфурола и кормовых дрожжей.

Ключевые слова: солома пшеницы, гидролиз, сернистая кислота, высокоэффективная анионообменная хроматография, моносахариды.
\end{abstract}

\section{Введение}

Растущий интерес к использованию растительной биомассы, богатой полисахаридами, обусловливает поиск оптимальных методов ее переработки. Образующиеся вторичные ресурсы агропромышленного

Харина Мария Владимировна - аспирант кафедры химической кибернетики, тел.: +7 (843) 231-40-10, факс: +7 (843) 238-56-94, e-mail: somariya@mail.ru Емельянов Виктор Михайлович - заведующий кафедрой химической кибернетики, доктор технических наук, профессор, тел.: +7 (843) 231-40-10, факс: +7 (843) 238-56-94, e-mail: emelianov@front.ru Аблаев Алексей Равильевич - аспирант кафедры химической кибернетики, тел.: +7 (495) 585-51-39, факс: +7 (495) 585-54-49, e-mail: aablaev@gmail.com Мокшина Наталья Евгеньевна - младший научный сотрудник, кандидат биологических наук, тел.: +7 (843) 231-90-41, факс: +7(843)292-73-47, e-mail: natalali@list.ru

Ибрагимова Надежда Николаевна - научный сотрудник, кандидат биологических наук, тел.: +7 (843) 292-53-32, факс: +7 (843) 292-73-47, e-mail: nibra@yandex.ru

Горикова Татьяна Анатольевна - заведующая лабораторией механизмов роста растительных клеток, доктор биологических наук, профессор,

тел.: +7 (843) 292-53-32, факс: +7 (843) 292-73-47, e-mail: gorshkova@mail.knc.ru комплекса могут служить источником ценных продуктов для химической промышленности и биотехнологических производств [1].

Несмотря на относительно высокую каталитическую активность серной, соляной и фосфорной кислот, их использование при гидролизе лигноцеллюлозы все еще экономически неэффективно, так как они обладают сильной коррозионной активностью, стоимость их высока, а нейтрализация их избытка в гидролизатах сопряжена с затратами и нагрузкой на окружающую среду [2].

Перспективным является применение сернистой кислоты, позволяющее сократить расход гидролизующего агента за счет его рекуперации (до $88 \%$ от используемого количества кислоты) [3]. Преимуществом применения сернистой кислоты является также то, что ее коррозионная активность гораздо ниже по сравнению с серной [4].

\footnotetext{
* Автор, с которым следует вести переписку.
} 
Ранее соавтором данной статьи были проведены эксперименты по гидролизу пшеничной соломы сернистой кислотой концентрацией 1-3\% масс. при варьировании температур в пределах $150-180{ }^{\circ} \mathrm{C}$ [5]. Было установлено, что применение сернистой кислоты позволяет повысить содержание редуцирующих веществ в гидролизате на $10 \%$ по сравнению с серной [6]. При исследовании гидролизатов пшеничной соломы авторы ограничились определением содержания редуцирующих и сухих веществ [5, 6]; полученные гидролизаты были использованы в составе питательных сред при культивировании различных штаммов микроорганизмов [7], при этом качественный состав углеводов в гидролизатах не оценивался. Таким образом, целью работы являлось исследование динамики влияния температуры $\left(150-200{ }^{\circ} \mathrm{C}\right)$ и длительности высокотемпературной обработки сернистой кислотой (0,59 и $1,18 \%$ масс.) пшеничной соломы на качественный и количественный составы углеводов в гидролизатах. Следует отметить, что основной причиной экономической неэффективности высокотемпературного гидролиза является высокий удельный расход электроэнергии, поэтому определение оптимального времени и условий высокотемпературного гидролиза, обеспечивающих снижение продолжительности процесса, является актуальной задачей.

\section{Экспериментальная часть}

В работе использовали высушенную на воздухе солому пшеницы Triticum sp., заготовленную по окончанию вегетационного периода (2011-2012 гг., Республика Татарстан). С целью увеличения реакционной способности пшеничную солому последовательно размалывали на двух мельницах: сначала на лабораторной мельнице Cemotec 1090 (FOSS TECATOR AB, Швеция), затем на QC-114 (Labor MIM, Венгрия). После измельчения солома фракционировалась с помощью набора сит. Для экспериментов использовали фракцию с размером частиц 1-3 мм. Измельченную солому высушивали при $102{ }^{\circ} \mathrm{C}$ в течение 2 ч для доведения до равновесной влажности.

Для определения легкогидролизуемых полисахаридов навеску пшеничной соломы гидролизовали в $2 \mathrm{M}$ трифторуксусной кислотой при $120^{\circ} \mathrm{C}$ в течение 1 ч. Для определения трудногидролизуемых полисахаридов оставшийся осадок гидролизовали $72 \%$ серной кислотой в течение 1 ч при $25^{\circ} \mathrm{C}$, затем добавляли воды (до конечной концентрации серной кислоты $3,4 \%$ ) и выдерживали при $120^{\circ} \mathrm{C}$ в течение 1 ч, раствор нейтрализовали гидроксидом бария [8]. Далее определяли моносахаридный состав полученных осветленных гидролизатов.

Высокотемпературный гидролиз растительного сырья осуществляли в термостатируемых капсулах на лабораторной установке оригинальной конструкции $[9,10]$, позволяющей проводить процессы химического гидролиза в рабочем диапазоне температур $100-200{ }^{\circ} \mathrm{C}$ при избыточном давлении $0-1,2$ МПа. Достоинством данной установки является возможность отбора проб реакционной массы в динамике, что позволяет оценить вклад временного фактора на выход углеводов и выявить оптимальную продолжительность процесса гидролиза. Гидролиз пшеничной соломы проводился 0,59\% масс. и $1,18 \%$ масс. растворами сернистой кислоты в диапазоне температур $150-200{ }^{\circ} \mathrm{C}$.

Содержание редуцирующих веществ определяли методом Макэна-Шоорля [11].

Для разделения высвобождающихся в процессе гидролиза пшеничной соломы полисахаридов и низкомолекулярных углеводов (моно- и олигосахаридов) к осветленным гидролизатам добавляли 96\% этиловый спирт до конечной концентрации 80\%. При добавлении этанола высокомолекулярные полимеры (полисахариды) выпадали в осадок, а низкомолекулярные углеводы оставались в надосадочной жидкости. Качественный состав моносахаридов оценивали методом высокоэффективной анионообменной хроматографии. Для определения содержания олигосахаридов проводили дополнительный гидролиз надосадочной жидкости $2 \mathrm{M}$ трифторуксусной кислотой при $120^{\circ} \mathrm{C}$ в течение 1 ч. Качественный и количественный составы олигосахаридов в гидролизате оценивали как разность между содержанием моносахаридов до и после проведения дополнительного гидролиза. Содержание полисахаридов в гидролизатах определяли по сухой массе осадка, образовавшегося при обработке проб этиловым спиртом.

Анализ моносахаридов проводили с помощью высокоэффективной анионообменной хроматографии на колонке CarboPac PA-1 (4×250 мм, «Dionex», США), используя импульсный амперометрический детектор PAD («Dionex»). Скорость элюирования 1 мл/мин. Температура колонки $30^{\circ} \mathrm{C}$. Буферы: A - 100 мM $\mathrm{NaOH}$ в $1 \mathrm{M} \mathrm{NaOAc,} \mathrm{B} \mathrm{-} 15$ мM NaOH. Градиентное элюирование проводили следующим образом: 0-20 мин В-100\%; 20-21 мин В-90\%, А-10\%; 22-41 мин В-50\%, А-50\%; 42-55 мин А-100\%; 56-85 мин B-100\%. Результаты анализировали с помощью программного обеспечения PeakNet. 
Эксперименты проводили в двукратной биологической повторности и трехкратной аналитической повторности. Погрешность реализации экспериментов при хроматографировании не превышала $\pm 0,21$ мг/мл.

\section{Обсуждение результатов}

Для характеристики исходного сырья было проведено определение качественного и количественного состава полисахаридов пшеничной соломы (табл. 1).

Набор и содержание углеводов, обнаруженных в исследуемой пшеничной соломе, согласовали с данными, приведенными в литературных источниках [1]. Общее содержание углеводов в пшеничной соломе составило 83,3\% от массы абсолютно сухого вещества соломы. Среди моносахаридов в соломе преобладали ксилоза и глюкоза. Содержание арабинозы также было высоким и составило 10,6\%. Высокое содержание ксилозы и арабинозы обусловлено тем, что среди связующих гликанов пшеничной соломы преобладает глюкуроноарабиноксилан [12]. Трудногидролизуемые полисахариды почти полностью состоят из глюкозы и представлены, вероятно, кристаллической целлюлозой, в то время как глюкоза, присутствующая во фракции легкогидролизуемых полисахаридов, содержится в аморфной целлюлозе или глюкане со смешанным типом связей - характерном полисахариде злаков [12].

С целью получения данных для построения кинетической модели был проведен высокотемпературный гидролиз пшеничной соломы в диапазоне температур $150-200{ }^{\circ} \mathrm{C}$ при концентрации сернистой кислоты 1,18\% масс. и гидромодуле $1: 5,8$ (табл. 2).

Согласно полученным данным, повышение температуры и концентрации кислоты приводит к существенному увеличению степени деполимеризации полисахаридов и сокращению времени достижения наибольшего выхода редуцирующих веществ. Как видно из таблицы 2, динамика изменения редуцирующих веществ в процессе гидролиза носит экстремальный характер, что обусловлено необратимыми процессами деструкции углеводов, протекающими под воздействием кислоты и высоких температур.

Таблица 1. Состав трудногидролизуемых и легкогидролизуемых полисахаридов пшеничной соломы

\begin{tabular}{l|c|c}
\hline \multicolumn{1}{c|}{ Моносахариды } & $\begin{array}{c}\text { Легкогидролизуемые полисахариды, \% от } \\
\text { массы абсолютно сухого вещества соломы }\end{array}$ & $\begin{array}{c}\text { Трудногидролизуемые полисахариды, \% от } \\
\text { массы абсолютно сухого вещества соломы }\end{array}$ \\
\hline Рамноза & 1,8 & 0 \\
Арабиноза & 10,4 & 0,2 \\
Галактоза & 3,8 & следы \\
Глюкоза & 13,3 & 14,1 \\
Ксилоза & 36,5 & 0,4 \\
Галактуроновая кислота & 1,5 & следы \\
Глюкуроновая кислота & 1,3 & следы \\
Общее количество & 68,6 & 14,7 \\
\hline
\end{tabular}

Таблица 2. Изменение концентрации редуцирующих веществ в ходе высокотемпературного гидролиза пшеничной соломы сернистой кислотой (жирным шрифтом выделена максимальная концентрация редуцирующих веществ)

\begin{tabular}{|c|c|c|c|c|c|c|c|c|c|c|}
\hline \multirow{3}{*}{ 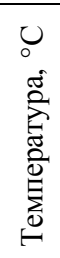 } & \multirow{3}{*}{ 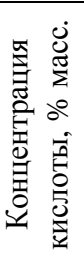 } & \multicolumn{9}{|c|}{ Концентрация редуцирующих веществ, \% } \\
\hline & & \multicolumn{9}{|c|}{ Время гидролиза, мин } \\
\hline & & 10 & 20 & 30 & 40 & 50 & 60 & 70 & 80 & 90 \\
\hline \multirow{2}{*}{150} & 0,59 & $0,3 \pm 0,04$ & $1,1 \pm 0,03$ & $1,2 \pm 0,54$ & $1,5 \pm 0,05$ & $1,5 \pm 0,04$ & $1,4 \pm 0,16$ & $2,3 \pm 0,51$ & $2,1 \pm 0,32$ & $2,3 \pm 0,32$ \\
\hline & 1,18 & $0,4 \pm 0,14$ & $1,3 \pm 0,05$ & $1,5 \pm 0,08$ & $1,9 \pm 0,10$ & $2,0 \pm 0,06$ & $2,0 \pm 0,14$ & $2,2 \pm 0,17$ & $2,1 \pm 0,10$ & $2,1 \pm 0$ \\
\hline \multirow{2}{*}{160} & 0,59 & $0,4 \pm 0,03$ & $1,3 \pm 0,03$ & $1,8 \pm 0,03$ & $1,8 \pm 0,03$ & $1,9 \pm 0,11$ & $1,7 \pm 0,03$ & $1,7 \pm 0,03$ & $1,6 \pm 0,03$ & $1,6 \pm 0,03$ \\
\hline & 1,18 & $0,7 \pm 0,26$ & $1,7 \pm 0,37$ & $2,1 \pm 0,56$ & $2,2 \pm 0,31$ & $2,1 \pm 0,23$ & $1,9 \pm 0,20$ & $2,0 \pm 0,07$ & $2,0 \pm 0,08$ & $2,0 \pm 0,16$ \\
\hline \multirow{2}{*}{170} & 0,59 & $0,7 \pm 0$ & $1,6 \pm 0,03$ & $\ldots$ & $1,9 \pm 0,04$ & $2,1 \pm 0,02$ & $2,1 \pm 0,07$ & $2,0 \pm 0,02$ & $1,9 \pm 0,03$ & $\ldots$ \\
\hline & 1,18 & $1,2 \pm 0,03$ & $2,2 \pm 0,03$ & $2,3 \pm 0,03$ & $2,5 \pm 0,03$ & $2,3 \pm 0,21$ & $2,2 \pm 0,26$ & $2,2 \pm 0,19$ & $2,1 \pm 0,20$ & $1,8 \pm 0,03$ \\
\hline \multirow{2}{*}{180} & 0,59 & $0,6 \pm 0,02$ & $1,8 \pm 0,27$ & $1,7 \pm 0,44$ & $2,2 \pm 0,30$ & $2,1 \pm 0,36$ & $2,0 \pm 0,26$ & $1,9 \pm 0,11$ & $1,8 \pm 0,14$ & $1,6 \pm 0,16$ \\
\hline & 1,18 & $1,0 \pm 0,44$ & $2,2 \pm 0,18$ & $2,5 \pm 0,23$ & $2,7 \pm 0,20$ & $2,0 \pm 0,25$ & $2,6 \pm 0,25$ & $2,4 \pm 0,29$ & $2,4 \pm 0,31$ & $\ldots$ \\
\hline \multirow{2}{*}{190} & 0,59 & $1,4 \pm 0,42$ & .. & $2,2 \pm 0,05$ & $2,0 \pm 0,25$ & $1,9 \pm 0,25$ & $1,5 \pm 0,40$ & $1,4 \pm 0,34$ & $1,3 \pm 0,28$ & $1,3 \pm 0,17$ \\
\hline & 1,18 & $1,4 \pm 0,03$ & $2,7 \pm 0,03$ & $2,7 \pm 0,03$ & $2,6 \pm 0,03$ & $2,4 \pm 0,03$ & $1,9 \pm 0,03$ & $1,9 \pm 0,03$ & $\ldots$ & $\ldots$ \\
\hline \multirow{2}{*}{200} & 0,59 & $0,6 \pm 0,03$ & $1,8 \pm 0,03$ & $2,1 \pm 0,03$ & $1,8 \pm 0,03$ & $1,9 \pm 0,03$ & $1,6 \pm 0,03$ & $1,5 \pm 0,03$ & $1,5 \pm 0,03$ & $1,4 \pm 0,03$ \\
\hline & 1,18 & $2,0 \pm 0,03$ & $3,0 \pm 0,03$ & $2,7 \pm 0,03$ & $2,2 \pm 0,03$ & $1,6 \pm 0,03$ & $\ldots$ & $\ldots$ & $\ldots$ & $\ldots$ \\
\hline
\end{tabular}


Определение содержания моносахаридов по концентрации редуцирующих веществ не является вполне точным и информативным. Свойства редуцирующих веществ в гидролизатах проявляют не только моносахариды (гексозы, пентозы, уроновые кислоты), но также и продукты их распада в кислой среде (фурфурол, метилфурфурол, гидроксиметилфурфурол) [13]. Для анализа моносахаридного состава (табл. 3) выбраны гидролизаты пшеничной соломы сернистой кислотой концентрацией 1,18\% масс., содержащие наибольшее количество редуцирующих веществ.

Из таблицы 3 следует, что в исследуемых гидролизатах преобладает ксилоза, содержание которой составило 48,4-55,1 моль \% от всех содержащихся моносахаридов. Наибольшее содержание ксилозы наблюдалось при обработке пшеничной соломы сернистой кислотой концентрацией $1,18 \%$ масс. при $170{ }^{\circ} \mathrm{C}$ в течение 40 мин, а также при $200{ }^{\circ} \mathrm{C}$ в течение 15 мин и составило 6,33 и 6,29 мг/мл соответственно. В гидролизатах отмечалось высокое содержание глюкозы - от 20,4 до 31,2 моль \%. Также высоко содержание арабинозы (10,8-15,3 моль \%). Содержание рамнозы в гидролизатах не превышало 2,5 моль \%. Таким образом, варьируя температуру и длительность гидролиза, можно регулировать моносахаридный состав гидролизатов в зависимости от их целевого назначения. Например, для извлечения арабинозы наиболее благоприятными температурами являются 150, 170 и $200{ }^{\circ} \mathrm{C}$. Наибольший выход общего количества моносахаридов наблюдается при обработке пшеничной соломы $1,18 \%$ сернистой кислотой при $170,180{ }^{\circ} \mathrm{C}$ в течение 40 мин и $200{ }^{\circ} \mathrm{C}$ в течение 15 мин.

Если выход продуктов деструкции растительной ткани зависит главным образом от природы происхождения лигноцеллюлозного сырья, то содержание в гидролизате продуктов разложения углеводов напрямую зависит от параметров процесса (гидромодуля, температуры, концентрации гидролизующего агента и длительности обработки) [13]. В связи с этим актуальным является исследование динамики выхода углеводов в процессе гидролиза с целью выбора оптимальных условий переработки пшеничной соломы для получения различных видов целевых продуктов и оценки доброкачественности получаемых гидролизатов.

Динамика образования моносахаридов в процессе высокотемпературного гидролиза пшеничной соломы изучалась на гидролизатах, полученных при обработке пшеничной соломы сернистой кислотой концентрацией 0,59\% масс. при $190{ }^{\circ} \mathrm{C}$ в интервале времени от 10 до 90 мин (см. рис. 1).

Из приведенных на рисунке 1 данных видно, что в наибольшей степени деструкции подвергалась ксилоза, содержание которой после достижения максимума на 25 мин резко снижалась со средней скоростью 0,06 мг/мл в мин.

Несмотря на то, что концентрация глюкозы в процессе гидролиза постепенно возрастала, наиболее перспективное время гидролиза пшеничной соломы при данных условиях - 25 мин, так как более длительный гидролиз приводит к образованию продуктов деструкции углеводов, способных ингибировать рост микроорганизмов при дальнейшей переработке гидролизатов, содержащих глюкозу [13]. Общее содержание моносахаридов в гидролизате составило 9,4\% от содержания легкогидролизуемых полисахаридов пшеничной соломы.

Таблица 3. Моносахаридный состав гидролизатов, полученных при обработке пшеничной соломы сернистой кислотой концентрацией $1,18 \%$ масс. в диапазоне температур $150-200{ }^{\circ} \mathrm{C}$

\begin{tabular}{|c|c|c|c|c|c|c|c|c|c|c|c|c|c|c|}
\hline \multirow{4}{*}{ 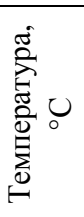 } & \multirow{4}{*}{ 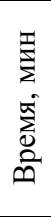 } & \multicolumn{10}{|c|}{ Содержание отдельных моносахаридов } & \multirow{3}{*}{\multicolumn{3}{|c|}{$\begin{array}{c}\text { Общее содержание } \\
\text { моносахаридов }\end{array}$}} \\
\hline & & \multicolumn{2}{|c|}{ рамноза } & \multicolumn{2}{|c|}{ арабиноза } & \multicolumn{2}{|c|}{ галактоза } & \multicolumn{2}{|c|}{ глюкоза } & \multicolumn{2}{|c|}{ ксилоза } & & & \\
\hline & & \multirow[t]{2}{*}{ МГ/Мл } & \multirow[t]{2}{*}{ моль\% ${ }^{*}$} & \multirow[t]{2}{*}{ мГ/мЛ } & \multirow[t]{2}{*}{ моль\% } & \multirow[t]{2}{*}{ МГ/МЛ } & \multirow[t]{2}{*}{ моль\% } & \multirow[t]{2}{*}{ Мг/Мл } & \multirow[t]{2}{*}{ моль\% } & \multirow[t]{2}{*}{ мГ/мЛ } & \multirow[t]{2}{*}{ моль \% } & & & \\
\hline & & & & & & & & & & & & МГ/МЛ & $\%^{* * *}$ & $\%^{* * * *}$ \\
\hline 150 & 70 & 0,18 & 1,9 & 1,42 & 15,3 & 0,80 & 7,1 & 2,28 & 20,4 & 4,97 & 53,4 & 9,9 & 6,9 & 10,1 \\
\hline 160 & 50 & 0,19 & 2,0 & 1,14 & 13,2 & 0,71 & 6,9 & 2,56 & 24,6 & 4,55 & 52,6 & 9,2 & 6,4 & 9,4 \\
\hline 170 & 40 & 0,35 & 2,5 & 1,72 & 13,5 & 1,10 & 7,1 & 4,07 & 26,5 & 6,33 & 49,5 & 13,7 & 9,6 & 13,9 \\
\hline 180 & 40 & 0,26 & 2,0 & 1,26 & 11,1 & 0,93 & 6,8 & 4,27 & 31,2 & 5,52 & 48,4 & 12,3 & 8,6 & 12,5 \\
\hline 190 & 25 & 0,22 & 2,1 & 1,13 & 10,8 & 0,76 & 7,3 & 3,27 & 28,0 & 5,0 & 51,2 & 10,5 & 7,3 & 10,7 \\
\hline 200 & 15 & 0,28 & 2,2 & 1,53 & 13,4 & 0,93 & 6,8 & 2,81 & 20,5 & 6,29 & 55,1 & 12,1 & 8,4 & 12,3 \\
\hline
\end{tabular}

" Доля данного моносахарида по отношению к другим моносахаридам в растворе (так как уроновые кислоты в гидролизатах содержались в следовых количествах, их содержание в таблице не приводится);

** от содержания углеводов в пшеничной соломе;

*** от содержания легкогидролизуемых полисахаридов в соломе. 
В анализируемых гидролизатах пшеничной соломы присутствовали олигосахариды (порядка $1 \%$ от легкогидролизуемых полисахаридов соломы), в составе которых преобладала глюкоза (рис. 2). Олигосахариды, содержащие ксилозу, детектировались на 10 и на 30 мин. Это свидетельствует о том, что связующие гликаны состоят из быстро- и медленногидролизуемых фракций: одна часть связующих гликанов может быть легко исключена из клеточных стенок, в то время как другие связующие гликаны более прочно связаны (например, ковалентной связью с лигнином) [2]. Различие в гидролизуемости ксиланов может быть также вызвано отличиями в их полимерной структуре, соотношении ацетильных и уроновых кислотных остатков.

На рисунке 3 представлена динамика образования моно-, олиго- и полисахаридов в процессе высокотемпературного гидролиза пшеничной соломы сернистой кислотой концентрацией 0,59\% масс. при температуре $190{ }^{\circ} \mathrm{C}$. Основной пик образования редуцирующих веществ и суммы углеводов приходился на 25 мин. Общая сумма углеводов в гидролизате на 25 мин составила 20,9\% от содержания легкогидролизуемых полисахаридов в соломе. Более $50 \%$ углеводов, содержащихся в исследуемых гидролизатах, представлено моносахаридами.

Значительный вклад также вносят и полисахариды, содержание которых на 25 мин составило 40,5\% от общего содержания углеводов в гидролизате (см. табл. 4) и 8,4\% от легкогидролизуемых полисахаридов. Содержание полисахаридов на 30 минуте достигало максимума и затем резко снижалось, что можно объяснить их деполимеризацией с образованием моно- и олигосахаридов.

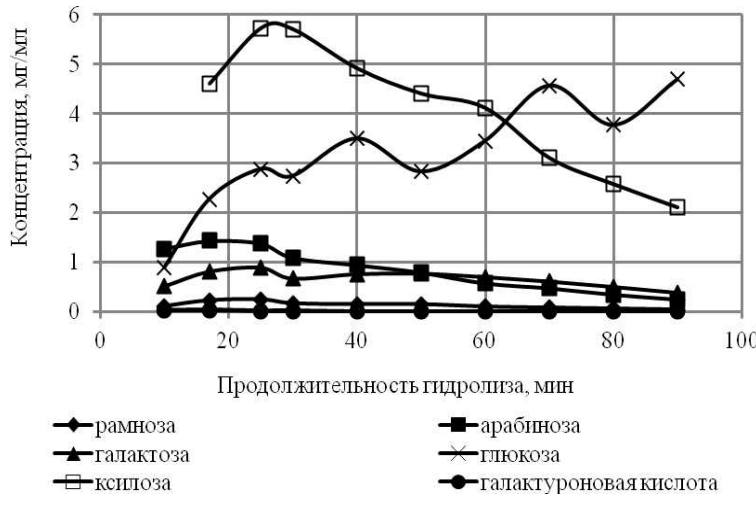

Рис. 1. Динамика образования моносахаридов в процессе высокотемпературного гидролиза пшеничной соломы сернистой кислотой концентрацией $0,59 \%$ масс. при $190{ }^{\circ} \mathrm{C}$

Рис. 3. Динамика выхода и деструкции моно-, олиго- и полисахаридов, а также редуцирующих веществ в процессе высокотемпературного гидролиза пшеничной соломы сернистой кислотой концентрацией 0,59\% масс. при температуре $190{ }^{\circ} \mathrm{C}$

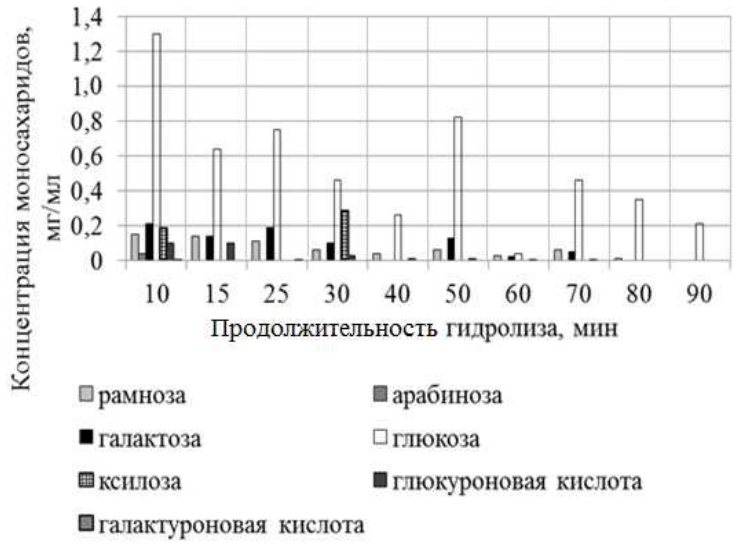

Рис. 2. Состав олигосахаридов гидролизатов, полученных при обработке пшеничной соломы $0,59 \%$ масс. сернистой кислотой при температуре $190{ }^{\circ} \mathrm{C}$

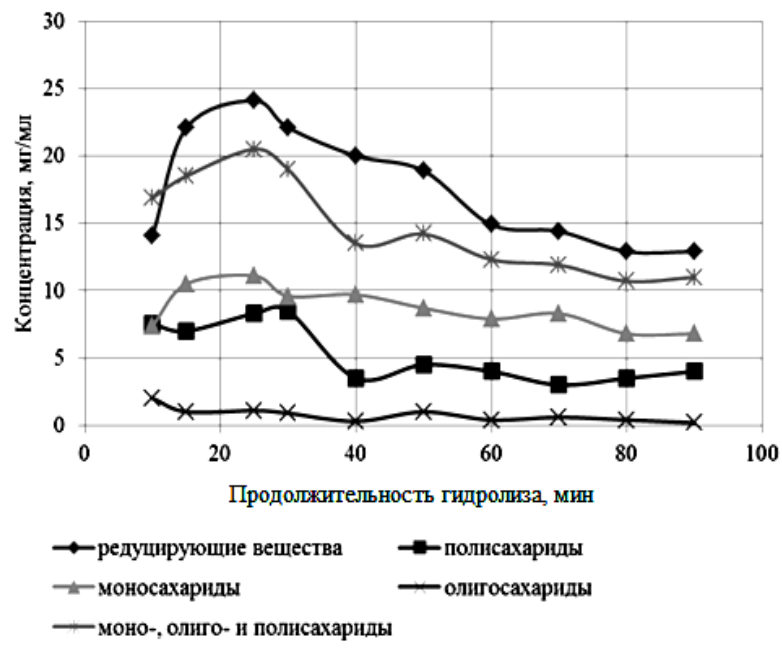


Таблица 4. Содержание моно-, олиго- и полисахаридов в гидролизатах, полученных при обработке пшеничной соломы 0,59\% масс. сернистой кислотой при температуре $190{ }^{\circ} \mathrm{C}$

\begin{tabular}{c|c|c|c|c|c|c|c|c|c|c|c|c}
\hline \multirow{2}{*}{$\begin{array}{c}\text { Время, } \\
\text { мин }\end{array}$} & \multicolumn{3}{|c|}{ Полисахариды } & \multicolumn{3}{c|}{ Моносахариды } & \multicolumn{3}{c|}{ Олигосахариды } & \multicolumn{3}{c}{$\begin{array}{c}\text { Моно-, олиго, и поли- } \\
\text { сахариды }\end{array}$} \\
\cline { 2 - 12 } & мг/мл & $\%^{*}$ & $\%^{* *}$ & мг/мл & $\%^{*}$ & $\%^{* *}$ & мг/мл & $\%^{*}$ & $\%{ }^{* *}$ & мг/мл & $\%^{*}$ & $\%^{* *}$ \\
\hline 10 & 7,5 & 5,2 & 7,6 & 7,4 & 5,2 & 7,5 & 2,0 & 1,4 & 2,0 & 16,9 & 11,8 & 17,2 \\
14 & 7,0 & 4,9 & 7,1 & 10,5 & 7,4 & 10,7 & 1,0 & 0,7 & 1,0 & 18,5 & 12,9 & 18,8 \\
$\mathbf{2 5}$ & $\mathbf{8 , 3}$ & $\mathbf{5 , 8}$ & $\mathbf{8 , 4}$ & $\mathbf{1 1 , 1}$ & $\mathbf{7 , 8}$ & $\mathbf{1 1 , 3}$ & $\mathbf{1 , 1}$ & $\mathbf{0 , 8}$ & $\mathbf{1 , 1}$ & $\mathbf{2 0 , 5}$ & $\mathbf{1 4 , 3}$ & $\mathbf{2 0 , 9}$ \\
30 & 8,5 & 5,9 & 8,6 & 9,6 & 6,7 & 9,8 & 0,9 & 0,6 & 0,9 & 19,0 & 13,3 & 19,3 \\
40 & 3,5 & 2,4 & 3,6 & 9,7 & 6,8 & 9,9 & 0,3 & 0,2 & 0,3 & 13,5 & 9,4 & 13,7 \\
50 & 4,5 & 3,1 & 4,6 & 8,7 & 6,1 & 8,9 & 1,0 & 0,7 & 1,0 & 14,2 & 9,9 & 14,4 \\
60 & 4,0 & 2,8 & 4,1 & 7,9 & 5,5 & 8,0 & 0,4 & 0,3 & 0,4 & 12,3 & 8,6 & 12,5 \\
70 & 3,0 & 2,1 & 3,1 & 8,3 & 5,8 & 8,4 & 0,6 & 0,4 & 0,6 & 11,9 & 8,3 & 12,1 \\
80 & 3,5 & 2,4 & 3,6 & 6,8 & 4,8 & 6,9 & 0,4 & 0,3 & 0,4 & 10,7 & 7,5 & 10,9 \\
90 & 4,0 & 2,8 & 4,1 & 6,8 & 4,7 & 6,9 & 0,2 & 0,1 & 0,2 & 11,0 & 7,6 & 11,2 \\
\hline
\end{tabular}

* От содержания углеводов в пшеничной соломе; ${ }^{* *}$ от содержания легкогидролизуемых полисахаридов в соломе.

\section{Выводы}

При гидролизе пшеничной соломы сернистой кислотой (0,59 и 1,18\% масс.), независимо от температуры воздействия $\left(150-200{ }^{\circ} \mathrm{C}\right)$, в исследуемых гидролизатах преобладала ксилоза $(48,4-55,1$ моль \% от суммы моносахаридов).

Наибольшее содержание ксилозы наблюдалось при обработке пшеничной соломы 1,18\% сернистой кислотой при $170{ }^{\circ} \mathrm{C}$ в течение 40 мин и при $200{ }^{\circ} \mathrm{C}$ в течение 15 мин и составило 6,33 и 6,29 мг/мл соответственно.

В ходе гидролиза пшеничной соломы сернистой кислотой $0,59 \%$ масс. при $190^{\circ} \mathrm{C}$ максимальный выход моно- и олигосахаридов наблюдался на 25 мин, моносахариды составили порядка $50 \%$ от общего содержания углеводов в гидролизате. Ксилоза подвергалась большей степени деструкции по сравнению с другими моносахаридами.

Благодаря высокому содержанию пентозанов и, в частности, ксилозы, гидролизаты пшеничной соломы сернистой кислотой перспективно использовать для получения ксилозы, ксилита фурфурола и кормовых дрожжей.

\section{Список литературы}

1. Сушкова В.И., Воробьева Г.И. Безотходная конверсия растительного сырья в биологически активные вещестBa. M., 2008. 216 c.

2. Scheper T., Tsao G.T. Recent progress in bioconversion of lignocellulosics. Berlin, 1999. 280 p.

3. Нуртдинов Р.М. Эффективность процессов осахаривания соломы и оценка качества гидролизатов для культивирования сахаромицетов : автореф. дис. ... канд. техн. наук. Казань, 2012. 20 с.

4. De Bari I., Nanna F., Braccio G. SO2-catalyzed steam fractionation of aspen chips for bioethanol production: Optimization of the catalyst impregnation // Industrial \& Engineering Chemistry Research. 2007. Vol. 46, N23. Pp. 77117720.

5. Нуртдинов Р.М., Мухачев С.Г., Валеева Р.Т., Емельянов В.М. Высокотемпературный гидролиз растительного сырья // Вестник Казанского технологического университета. 2011. №10. С. 204-208.

6. Нуртдинов Р.М., Валеева Р.Т., Мухачев С.Г. Низкотемпературный гидролиз растительного сырья // Вестник Казанского технологического университета. 2011. №15. С. 150-153.

7. Мухачев С.Г., Валеева Р.Т., Нуртдинов Р.М. Питательная среда для генерации биомассы сахаромицетов // Производство спирта и ликероводочных изделий, 2011. №3. С. 20-23.

8. Stephen S. Fry The growing plant cell wall: chemical and metabolic analysis. New York,1988. 121 p.

9. Мухачев С.Г., Емельянов В.М., Шавалиев М.Ф., Елчуев Р.Т., Валеева Р.Т., Нуртдинов Р.М., Буйлин А.М. Биотехнологический комплекс учебной лаборатории энерго- и ресурсосбережения // Вестник Казанского технологического университета. 2009. №5. С. 21-26.

10. Нуртдинов Р.М., Мухачев С.Г., Валеева Р.Т., Емельянов В.М., Шавалиев М.Ф., Шагивалеев И.В., Якушев И.А. Разработка биотехнологического комплекса переработки растительного сырья и отходов сельскохозяйственного производства // Вестник Казанского технологического университета, 2011. №2. С. 143-147.

11. Жданов Ю.А., Дорофеенко Г.Н. Практикум по химии углеводов. 2-е изд., перераб. и доп. М., 1973. 204 с.

12. Carpita N, McCann M (2000) The cell wall. In: Buchanan B, Gruissem W, Jones R (eds) Biochemistry and molecular biology of plants. Am. Soc. of Plant Physiol, Rockville. Pp. 52-108.

13. Бровенко Г.Н., Гусельникова Т.В. Химический состав гидролизатов древесины - субстрата для микробиологического синтеза белка (обзор литературы). Фурфурол и оксиметилфурфурол // Гидролизная и лесохимическая промышленность. 1993. №1. С. 6-10. 
Kharina M.V..$^{{ }^{*}}$, Emelyanov V.M. ${ }^{1}$, Ablaev A.R. ${ }^{1}$, Mokshina N.E. ${ }^{2}$, Ibragimova N.N. ${ }^{2}$, Gorshkova T.A. ${ }^{2}$ DYNAMICS OF CARBOHYDRATES YIELD DURING THE HIGH TEMPERATURE HYDROLYSIS OF WHEAT STRAW WITH SULFUROUS ACID

${ }^{1}$ Kazan National Research Technological University, 68 Karl Marx street, Kazan, 420015, (Russian Federation), email:emelianov@front.ru

${ }^{2}$ Institute of Biochemistry and Biophysics, Kazan Scientific Center of the Russian Academy of Sciences, 2/31

Lobachevsky street, Kazan, 420111, (Russian Federation), e-mail: gorshkova@mail.knc.ru

The influence of temperature and time treatment on the composition and content of carbohydrates of wheat straw hydrolysates with sulfurous acid $(0, .59$ and $1,18 \%$ wt.) was investigated. The maximum yield of sugars in hydrolysates obtained at temperatures of $150-200{ }^{\circ} \mathrm{C}$ did not exceed $10 \%$ of the total carbohydrate content of the straw. Irrespective of the temperature effects in the hydrolysates xylose predominated (48,4-55,1 mol\% of monosaccharides). The dynamics of mono-, oligo-and polysaccharide yeld during hydrolysis of wheat straw with sulfurous acid $0,59 \%$ wt. at $190{ }^{\circ} \mathrm{C}$ was analyzed. Due to the high content of pentoses, and in particular, xylose, obtained hydrolysates for produce xylose, xylitol and furfural, fodder yeast could be used.

Keywords: wheat straw, hydrolysis, sulfurous acid, high performance anion exchange chromatography, monosaccharides.

\section{References}

1. Sushkova V.I., Vorob'eva G.I. Bezotkhodnaia konversiia rastitel'nogo syr'ia v biologicheski aktivnye veshchestva. [Waste-free conversion of plant materials into biologically active substances]. Moscow, 2008, 216 p. (in Russ.).

2. Scheper T., Tsao G.T. Recent progress in bioconversion of lignocellulosics. Berlin, 1999. 280 p.

3. Nurtdinov R.M. Effektivnost' protsessov osakharivaniia solomy $i$ otsenka kachestva gidrolizatov dlia kul'tivirovaniia sakharomitsetov: avtoref. dis. ... kand. tekhn. nauk. [Saccharification process efficiency and quality assessment straw hydrolysates for the cultivation of Saccharomyces: Abstract of the thesis Candidate of Technical Sciences]. Kazan, 2012, 20 p. (in Russ.).

4. De Bari I., Nanna F., Braccio G. Industrial \& Engineering Chemistry Research, 2007, vol. 46, no. 23, pp. 7711-7720.

5. Nurtdinov R.M., Mukhachev S.G., Valeeva R.T., Emel'ianov V.M. Vestnik Kazanskogo tekhnologicheskogo universiteta, 2011, no. 10, pp. 204-208. (in Russ.).

6. Nurtdinov R.M., Valeeva R.T., Mukhachev S.G. Vestnik Kazanskogo tekhnologicheskogo universiteta, 2011, no. 15, pp. 150-153. (in Russ.).

7. Mukhachev S.G., Valeeva R.T., Nurtdinov R.M. Proizvodstvo spirta i likerovodochnykh izdelii, 2011, no. 3, pp. $20-23$. (in Russ.).

8. Stephen S. Fry The growing plant cell wall: chemical and metabolic analysis. New York,1988. 121 p.

9. Mukhachev S.G., Emelianov V.M., Shavaliev M.F., Elchuev R.T., Valeeva R.T., Nurtdinov R.M., Builin A.M. Vestnik Kazanskogo tekhnologicheskogo universiteta, 2009, no. 5, pp. 21-26. (in Russ.).

10. Nurtdinov R.M., Mukhachev S.G., Valeeva R.T., Emelianov V.M., Shavaliev M.F., Shagivaleev I.V., Iakushev I.A. Vestnik Kazanskogo tekhnologicheskogo universiteta, 2011, no. 2, pp. 143-147. (in Russ.).

11. Zhdanov Iu.A., Dorofeenko G.N. Praktikum po khimii uglevodov. [Workshop on carbohydrate chemistry]. Moscow, 1973, 204 p. (in Russ.).

12. Carpita N, McCann M (2000) The cell wall. In: Buchanan B, Gruissem W, Jones R (eds) Biochemistry and molecular biology of plants. Am. Soc. of Plant Physiol, Rockville, pp 52-108

13. Brovenko G.N., Gusel'nikova T.V. Gidroliznaia i lesokhimicheskaia promyshlennost', 1993, no. 1, pp. 6-10. (in Russ.).

Received September 5, 2013

\footnotetext{
* Corresponding author.
} 
